\title{
Republicans seek to widen cloning ban
}

[WASHINGTON] Almost as soon as President Bill Clinton's proposed law to outlaw human cloning reached the US Congress last week, it became evident that it does not go far enough for many Republicans.

Conservative Republicans in the House of Representatives and the Senate promised to push for a tougher law to ban permanently not only human cloning for the purposes of reproduction, but also the use of cloning in the private sector to create research embryos not intended for implantation.

Clinton's Cloning Prohibition Act has been drafted in response to the recommendations of the president's National Bioethics Advisory Commission (NBAC). It would ban for five years "any attempt to create a human being using somatic cell nuclear transfer cloning", the method used by Scottish scientists who announced in February that they had cloned Dolly the sheep (see Nature 385, 810-813; 1997.)

The act would impose a fine of at least $\$ 250,000$ on anyone caught attempting to do so, and additional profits would be liable to seizure. The NBAC would be required to recommend whether the law should be renewed as its expiry date approached.

The bill has not been introduced in Congress, a procedure that requires a member of the House or Senate to sponsor it. None has stepped forward to do so, although it was not clear last week whether this is due to reticence or to simple procedural delays.
But, at hearings in the House and Senate last week, two politicians who have already introduced anti-cloning bills of their own complained that the Clinton measure - and the NBAC recommendations on which it is founded - are morally inadequate.

Senator Christopher Bond (Republican, Missouri) complained that the NBAC had avoided a politically charged issue by remaining silent about embryos created by cloning but not implanted. He said: "By allowing cloning research on human embryos in the private sector, the commission said: 'Go ahead as far as you can; when it gets dangerous then we'll try and stop you.'

Bond said this approach — also implicit in the Clinton bill — "risks sliding very far down the slope" to human cloning and that tighter controls were necessary.

Both Bond and Congressman Vern Ehlers (Republican, Michigan) insisted that any legal ban should be permanent. Ehlers, a physicist by training, has introduced two bills — one to outlaw cloning for the purposes of reproduction, and the other to outlaw research toward this goal.

Ehlers said that the House would not stay silent on whether to allow private production of cloned embryos for research.

He suggested that any debate would require the House to discuss a broader question - why human embryo research should be allowed in the private sector at all. Current US law bans federally funded human embryo research in which embryos are harmed or destroyed, but such research is allowed in the private sector.

At the House hearing, even liberal politicians questioned the consistency of the NBAC recommendation. Sheila Jackson Lee (Democrat, Texas) declared that the question of unrestricted activity in the private sector "looms".

"How do you [rationalize] that bifurcated" recommendation, she asked Harold Shapiro, the NBAC chairman and president of Princeton University. Shapiro responded that different standards apply when contentious moral questions relate to taxpayerfinanced activities as opposed to private ones.

George Annas, professor of law and public health at Boston University, suggested that, for anti-abortionists, the Clinton bill is "the worst of both worlds", as it allows the creation of research embryos in the private sector, and requires their destruction.

Annas speculated that Congress was more likely to prohibit all research on human embryos than explicitly to sanction research on human embryos with no chance of implantation. He also said that Congress was unlikely to be content with the civil penalties in the Clinton bill.

"The president's [bill says] it's wrong to do this because it puts the [resulting] children at a very grave risk of genetic harm," Annas said. "I think Congress will determine this is a felony."

MeredithWadman

\section{Palaeontologists protest at Web sale of hominid remains}

[LONDON] An undergraduate palaeontology student from Texas, who caused controversy last month by trying to sell a Tyrannosaurus rex skeleton through the World Wide Web, has caused a further stir by selling a hominid skull and jawbones to an undisclosed university in Europe.

Jim Wyatt, a student at the University of Texas, Dallas, owns Fossilnet, an electronic 'supermarket' of fossils. Earlier this month, he put pictures on his website of what are believed to be Cro-Magnon and Neanderthal human remains from Italy, including a skull (right) valued at US\$28,000.

The European university, which has a large department of palaeoanthropology, is believed to have struck a deal at the start of the month. The skull and seven other items were jointly priced at $\$ \mathbf{9 4 , 0 0 0}$. But Wyatt says the university paid "substantially below the asking price".

The items are part of a private collection that once belonged to an Italian fossil hunter, Frederic Zambelli Hosmer. They are believed to have been excavated in the 1920s and '30s, and sold by Zambelli to

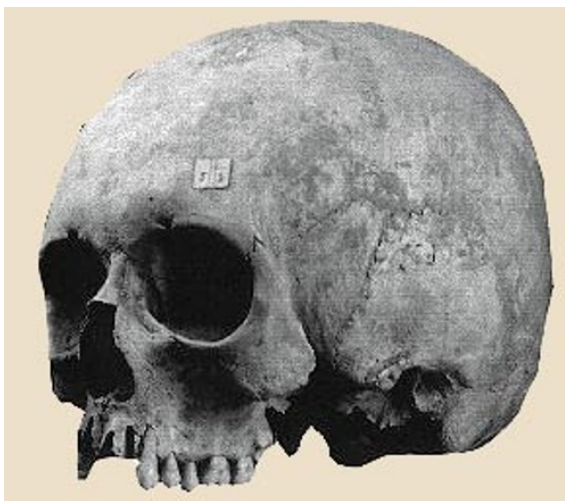

finance his explorations.

Last month, Wyatt angered members of the Society for Vertebrate Paleontology by using as the showpiece item of his website a virtually complete - and still unsold privately owned skeleton of $T$. rex with a price of \$12 million.

His decision to sell human remains "is just going too far", says Eric Scott, palaeontology field supervisor at the San Bernardino County Museum in California. "Many people have objected to the sale of dinosaur skeletons. But selling human material is just frightening. And there's so little of it around."

Wyatt claims to earn less than $\$ 50,000$ a year, mostly by brokering small-scale deals between private collectors and museums and universities. "What I'm doing is totally legal, and no different to any other business," he says.

Buying and selling fossils brought legally from another country is permitted in the United States, as is fossil collection on private land. A proposed bill — the Fossil Preservation Act of 1996 - would even permit commercial fossil collection on public land.

The Society for Vertebrate Paleontology is opposed to this, as is the public. A clear majority of respondents to a survey conducted two years ago said they believed fossils found on public or private land should belong to public institutions (see Nature 379, 388; 1996).

An associated organization, Save America's Fossils for Everyone (SAFE), has drafted its own fossil-preservation proposals as a draft Senate bill.
Ehsan Masood 